\title{
BENEFITS OF REIKI IN OLDER INDIVIDUALS WITH CHRONIC PAIN
}

\author{
Vera Lucia Freitag' ${ }^{1}$ Indiara Sartori Dalmolin², Marcio Rossato Badke ${ }^{3}$ Andressa de Andrade
}

\footnotetext{
${ }^{1}$ Master's degree student in the Graduate Program in Nursing of the Universidade Federal de Pelotas (UFPel). Pelotas, Rio Grande do Sul, Brazil. E-mail: verafreitag@hotmail.com

${ }^{2}$ Resident Nurse in the Integrated Multidisciplinary Residency Program in Family Health at the Universidade Federal de Santa Catarina. Florianópolis, Santa Catarina, Brazil. E-mail: indiarasartoridalmolin@yahoo.com.br

${ }^{3}$ Ph.D. student the Graduate Program in Nursing of the UFPel. Assistant Professor at Universidade Federal de Santa Maria (UFSM). Palmeira das Missões, Rio Grande do Sul, Brazil. E-mail: marciobadke@yahoo.com.br

${ }^{4}$ Ph.D. student in the Health Sciences Program at the Federal Universidade Federal de Rio Grande. Assistant Professor at UFSM. Palmeira das Missões, Rio Grande do Sul, Brazil. E-mail: andressaufsm@gmail.com
}

\begin{abstract}
Reiki is characterized as a complementary therapy which involves the laying on of hands on human beings with the intention to re-establish the physical, mental and spiritual balance. The objective of this study was to identify and analyze the benefits experienced with the practice of Reiki in older individuals with chronic non-cancer pain. This is a qualitative, descriptive and exploratory study. Semi-structured interviews, with open and closed-ended questions, were used for data collection. Data were collected between July and August of 2012. The study subjects were ten older patients with chronic non-cancer pain complaints, submitted to five Reiki sessions. The analysis proposed by Bardin was considered to evaluate the results. In conclusion, this therapeutic practice significantly improves chronic pain complaints, in addition to contributing to the balance of the physical, mental, emotional and spiritual needs of older people.
\end{abstract}

DESCRIPTORS: Complementary therapies. Nursing. Pain.

\section{BENEFÍCIOS DO REIKI EM POPULAÇÃO IDOSA COM DOR CRÔNICA}

RESUMO: O Reiki caracteriza-se como uma terapia complementar realizada através da imposição das mãos no ser humano, com a intenção de restabelecer o equilíbrio físico, mental e espiritual. O objetivo desta pesquisa foi identificar e analisar os benefícios vivenciados com a prática de Reiki em indivíduos idosos com dor crônica não-oncológica. Trata-se de um estudo qualitativo, descritivo e exploratório. Para coleta de dados foi utilizada a entrevista semiestruturada, com questões abertas e fechadas. Os dados foram coletados entre os meses de julho e agosto de 2012. Os sujeitos do estudo foram dez idosos com queixas de dor crônica não oncológica, submetidos a cinco sessões de Reiki. Para a avaliação dos resultados considerou-se a análise de conteúdo proposta por Bardin. Concluiu-se que esta prática terapêutica melhora de forma significativa as queixas de dor crônica, além de contribuir para o equilíbrio das necessidades física, mental, emocional e espiritual dos idosos.

DESCRITORES: Terapias complementares. Enfermagem. Dor.

\section{BENEFICIOS DEL REIKI EN LA POBLACIÓN DE EDAD AVANZADA CON DOLOR CRÓNICO}

RESUMEN: Reiki se caracteriza por ser una terapia complementar llevado a cabo a través de la imposición de manos en el ser humano con la intención de restablecer el equilibrio físico, mental y espiritual. El objetivo de esta investigación fue identificar y analizar los beneficios experimentados con la práctica de Reiki, en sujetos ancianos con dolor crónico no oncológica. Se trata de un estudio cualitativo, descriptivo y exploratorio. Para la recolección se utilizó la entrevista semiestructurada, con cuestiones abiertas y cerradas. Los datos fueron recogidos entre julio y agosto de 2012. Los sujetos del estudio fueron diez ancianos con quejas de dolor crónico no oncológica, presentó las cinco sesiones de Reiki. Evaluación de resultados se considera el análisis del contenido propuesto por Bardin. Se concluyó que esta práctica terapéutica mejora significativamente las quejas de dolor crónico, además de contribuir al equilibrio de las necesidades físicas, mentales, emocionales y espirituales de los ancianos.

DESCRIPTORES: Terapias complementarias. Enfermería. Dolor. 


\section{INTRODUCTION}

Reiki is a healing system through the laying on of hands, used for the treatment of the physical body, acting on the ethereal, mental, emotional and spiritual subtle bodies, bringing benefits that go beyond the physical body and act deeply, not only on symptoms, but on their actual cause. ${ }^{1}$ It is a useful type of therapy offered to individuals in situations of health and sickness, since it increases the vital energy and strengthens the immune system. ${ }^{2}$

The Japanese word rei-ki is composed of two syllables: rei, which describes the cosmic, universal aspect and energy, and $k i$, which means the fundamental life force flowing and pulsating in all living beings individually. It represents a simple curing method that allows the absorption of more vital energy, strengthening and balancing the energy of human beings. The laying on of hands, by the Reiki method, directs healing energy to the recipient's body, which flows vigorously. The Reiki donor serves as a channel to convey universal life energy. Thus, no personal energy is absorbed or drained from the donor, which is simultaneously recharged and strengthened after each Reiki session. ${ }^{3}$

The vital force transmitted by this method covers the entire system of endocrine glands and organs of the body, energizing human beings at various levels simultaneously: the physical level, by the warmth of the hands; the mental level, by the Reiki symbols or thoughts; the emotional level, by the love that flows from them; and the energy level, by the presence of the person initiated in this therapy and by the Reiki energy itself. ${ }^{4}$

The method has a preventive and harmonizing character, always acting on the cause of the problems, since it treats the physical, psychological, mental and spiritual, with concrete results on anxiety, pain, stress, depression, insomnia, fear, insecurity, panic, as well as on the organs, tissues and systems, caring for others in a comprehensive manner. $^{2}$

The concept of pain used worldwide today was originated from the International Association for the Study of Pain (IASP), which characterizes it as an unpleasant sensory and emotional experience, arising from actual or potential tissue damage in the body of the individual. It is basically a subjective manifestation, varying in appreciation from person to person. ${ }^{5}$ When pain manifests itself for a period greater than six months, it is characterized and defined as chronic, causing high costs to the health system and affecting several social and economic segments. ${ }^{6}$ Older people become more susceptible to developing chronic pain since they are more exposed to trauma, infection and chronic degenerative diseases, responsible for this type of pain. About $85 \%$ of people aged over 65 have at least one health problem that predisposes pain. This is considered as frequent in about 32 to $34 \%$ of older individuals, occasional in 20 to $25 \%$, acute in 6 to $7 \%$ and chronic in $48 \%$ to $55 \%$ of these. ${ }^{7}$ In this context, it is believed that the practice of Reiki as a complementary therapy can contribute as a method of care based on prevention, relief from the symptoms and for healing chronic pains.

To ensure the health care comprehensiveness, the Ministry of Health created the National Policy on Integrative and Complementary Practices (PNPIC, as per its acronym in Portuguese) in the Brazilian Unified Health System (SUS, as per its acronym in Portuguese) in 2006, whose implementation involves political, technical, economic, social and cultural reasons. This policy addresses the need to know, support, incorporate and implement experiences that have been developed in the public health network of many municipalities and states, especially those from the Traditional Chinese Medicine - Acupuncture, Homeopathy, Herbal Medicine, Anthroposophical Medicine, and Hydrotherapy-Crenotherapy. ${ }^{8}$

The professionals working with Integrative and Complementary Practices (ICPs) encourage subjects to find their well-being and balance, once they understand that the body, as well as nature, has the capacity to search for the balance of well-being and thereby improve the quality of life. ${ }^{9}$

A study was carried out in England with the aim to investigate whether complementary Reiki therapy had any effect on the function of the autonomic nervous system of the recipients. Forty-five subjects, randomly assigned into three groups, participated in the survey: without treatment; receiving Reiki treatment by an experienced practitioner and a placebo group receiving Reiki by a person with no knowledge of the therapy who imitated the traditional treatment. The heart rate, vagal cardiac tone, blood pressure, cardiac sensitivity to baroreflex and respiratory activity were measured. The results indicate that the heart rate and diastolic blood pressure decreased significantly in the Reiki group compared with 
the control and placebo groups, indicating that the treatment has some effect on the autonomous nervous system. ${ }^{10}$

Another relevant study had the aim to evaluate the results of the application of Reiki in voluntary patients from a medical oncology center. Qualitative data were obtained from written answers to questions asked after each session of Reiki. The results showed a decrease of more than $50 \%$ of suffering characterized by anxiety, depression, pain and fatigue. The volunteers reported that they would like to continue using Reiki, as they obtained relaxation and felt spiritual well-being. ${ }^{11}$

Research publications on the Reiki subject, associated with the experiences lived with supervised practical activities during the undergraduate nursing course, spurred interest to carry out this study. Furthermore, the idea of working with Reiki is founded on the life of one of the authors who sought to learn about this form of complementary treatment for years.

In previous empirically experienced experiments by that author, it was found that individuals mention well-being and the reduction of stress during and after the application of Reiki, even reporting relief from acute and chronic pain. Therefore, it sparked interest in further discussions about the theme, since the nursing care needs to be closely linked to scientific knowledge and thus actively participating in the construction of this knowledge. In this sense, the objective of the research was to identify and analyze the benefits experienced by older individuals with chronic non-cancer pain after the application of Reiki.

\section{METHODOLOGY}

This is a survey of qualitative, ${ }^{12}$ exploratory and observational nature. The subjects were ten older residents from two towns in the northern region of the state of Rio Grande do Sul. A simple random sample was used. The inclusion criteria for the study were: having chronic non-cancer pain at the time of the study, being a member of the senior group, being aged 60 years or more, being able to read and write, committing to participate voluntarily in five sessions of Reiki and, also, responding to an interview. The exclusion criterion considered was: physical and intellectual incapacity to respond to the questionnaires.

Initially, the project was presented to the members of the senior groups, in order to know how many people met the inclusion criteria and were interested in participating in the research. In order to maintain the anonymity of the participants, they were identified by the following mantras (OM, LAM, RAM, YAM, KAM, VAM, HAM, AUM, KLIM and GAM). The Reiki sessions were applied individually on five consecutive days by a Reikian nursing academic. Each session lasted for one hour, using fourteen positions with the laying on of hands, namely four on the head, four on the thoraco-abdominal area, four positions in the back region and two in the lower limbs. The positions were the same in all sessions and for all subjects. Sites used for the routine encounters of the senior groups were used, but in a restricted room.

In addition to the Reiki sessions, a semistructured interview containing open and closedended questions was used as an instrument for data collection; the closed-ended questions were related to sociodemographic characteristics of the subjects, and the open ones were directed at the topic of Reiki, allowing the interviewee to be more at ease in responding to the inquiries. The data were recorded and then completely transcribed. The collection was carried out from July to August of 2012, in the senior groups' meeting places. The interview was conducted before the first and after the fifth Reiki session.

The verbal scale was used to check the intensity of pain, in which the patient quantified the painful experience using phrases that represent different intensities of pain, such as: no pain, mild pain, moderate pain, severe pain, unbearable pain and the worst pain possible, valid and reliable in measuring older people's painful experience. ${ }^{13}$ The scale was applied before the first and after the fifth session of Reiki.

In order to organize the observations with the participant, a script of observations was created with six items to be observed and recorded in a field diary, namely: felt the urge to lie down on the stretcher; breathing, movement; position in which the subject began to relax; if the subject felt sleepy, slept; if they felt different vibrations in certain regions of the body; and overall appearance after the session. The observations carried out in each session of Reiki were recorded in this diary.

The analysis of the content followed three steps according to Bardin: 1) pre-analysis; 2) exploration of the material; and 3) treatment of the results, inference and interpretation. ${ }^{14}$ 
Therefore, to perform each of the steps of the above-mentioned methodology, the purpose of this study was readdressed at first, in order to systematize the initial concepts of the research. Then, a thorough reading of the material to be analyzed was conducted, in which each one of the recorded audio interviews was listened to, thus taking in all of the content. Subsequently, the interviews were fully transcribed into a document created in the Microsoft Office Word 2010 program.

The next step dealt with the exploration of the material. At this stage, we tried to search for significant words or expressions that emerged in the transcripts, and which, therefore, constituted and categorized the corpus.

To appreciate and ensure ethical conduct throughout the research process, the project was registered in the Project Office/UFSM, under n. 031219. Data were collected once the research proposal was approved by the Research Ethics Committee at the UFSM, with CAAE (Certificate of Submission for Ethical Appreciation) $n$. 01461812.8.0000.5346, and the Free and Informed Consent Form (FICF) was signed by the participants. The guidelines and provisions of resolution no. 196/96, ${ }^{15}$ of the Brazilian Ministry of Health, which describes the guidelines and regulations governing investigative processes involving human subjects, were observed and their recommendations met at all stages of the research.

\section{RESULTS AND DISCUSSION}

Ten older patients with complaints of chronic non-cancer pain participated in the study, five men and five women; six participants ranged in age from 60 to 70 years and four between 70 and 80 years.

Regarding occupation, nine subjects reported being farmers and one person was a housewife, all had schooling between the 2 nd and 6 th grades of elementary school. Among the participants, six were from municipalities located in the North, two from the North West region and two from Central region of the state of Rio Grande do Sul. The predominant religion was Catholic (nine subjects), followed by the Evangelical (one subject).

After the fifth session of Reiki, two subjects reported no pain, seven subjects reported mild pain and one subject reported severe pain. Thus, among the respondents, the majority showed some kind of improvement after the sessions. Four subjects who reported moderate pain in the spine, lumbosacral region and joints, before the Reiki sessions, began to refer to mild pain; one person with moderate localized pain in the lumbosacral region and spinal column reported no pain; two subjects who reported severe pain in the lumbosacral region and knees started reporting mild pain; one who had severe pain in the scapular and lumbosacral region reported no pain; another that referred to unbearable pain in the joints and spine reported mild pain and only one subject who reported pain in the spine, lower back and joints revealed no improvement, stating that before the sessions he had severe pain and that it remained strong (Table 1). It is worth highlighting that this participant, alongside the Reiki sessions, was being subjected to motor physiotherapy sessions, which may have influenced the results.

Table 1 - Intensity of pain before and after the Reiki sessions, 2012

\begin{tabular}{|c|c|c|}
\hline Subject & $\begin{array}{c}\text { Intensity of pain } \\
\text { before sessions }\end{array}$ & $\begin{array}{c}\text { Intensity of pain } \\
\text { after sessions }\end{array}$ \\
\hline KAM & Moderate & None \\
\hline VAM & Moderate & Mild \\
\hline KLIM & Moderate & Mild \\
\hline GAM & Heavy & Heavy \\
\hline AUM & Moderate & Mild \\
\hline QAM & Unbearable & Mild \\
\hline YAM & Heavy & Mild \\
\hline LAM & Moderate & Mild \\
\hline OM & Heavy & Mild \\
\hline HAM & Heavy & None \\
\hline
\end{tabular}

Two thematic categories emerged from the qualitative analysis of the speeches: Reiki therapy in chronic pain relief and the practice of Reiki as a care tool: providing physical and psychological well-being.

\section{Reiki therapy in chronic pain relief}

This category was identified and reported by observing that the majority of respondents mentioned a significant improvement in chronic pain, some since the second session of Reiki, as it can be seen in the following statement: 
$[. .$.$] the pains have improved a lot, [...] the leg$ pain improved, it's moderate, I don't have such a bad headache anymore, the leg pain improved a lot too, the back pain improved, because when I got up I had pain that I could not endure (LAM).

It is evident that nowadays increasingly more individuals are affected by health-related problems. Many of these problems are accompanied by pain and, in a significant portion of them, chronic pain is the individual's main complaint, which may interfere significantly in the quality of life of older individuals. ${ }^{7}$

Population aging has contributed to the prevalence of chronic and disabling diseases in this section of the public, leading to functional limitation and decreasing autonomy of the subject. Chronic pain is a major problem, as it significantly hinders the independence of older people in carrying out their daily functions, affecting their quality of life. ${ }^{16}$

Before the first session, the subjects complained of pain in the joints, spine, lumbosacral and knees, in addition to having signs and symptoms of anxiety, stress, nervousness, insomnia, and difficulty in performing daily activities. It is noteworthy that these signs and symptoms are common among older adults and, in most cases, associated with depressive disorders and organic diseases. After completing the five Reiki sessions, the subjects verbally demonstrated relief from pain, a good sleep pattern, smooth execution of day-to-day tasks, improvement in levels of stress and anxiety, change in thought processes and good mood.

Many studies have been developed to show the results obtained with the application of Reiki, including the assessment for the laying on of hands on mice, assessing hematological and immunological parameters. The results of this research showed that, in the animals that received the laying on of hands, there was a significant decrease in platelet count, an increase in the number of monocytes in the specific leukocyte count, increased cytotoxic activity of non-adherent cells with activity of cells and natural-killer and killer cells activated by lymphokines. The control and placebo groups showed no change. The results found led to the conclusion that there is a physiological change resulting from the laying on of hands and that further studies considering such evidence are needed. ${ }^{17}$

Another relevant study had the objective of investigating the immediate effects of Reiki on the salivary immunoglobulin A (IgAs), in the activity of a-amylase and blood pressure in nurses suffering from Burnout syndrome. A randomized, double-blind and placebo-controlled clinical trial, with crossover design, was conducted. Eighteen nurses (aged between 34 and 56 years), with Burnout syndrome, participated in the study. The participants received treatment with Reiki or false Reiki, according to the order established by randomization, on two separate days. The study found a significant relationship between the timing of the intervention and diastolic blood pressure, showing that a Reiki session of 30 minutes can immediately improve the IgAs response and diastolic blood pressure in nurses with Burnout syndrome. ${ }^{18}$

No specific studies related to chronic pain relief after application of Reiki were found. In this context, this study highlights the importance of Reiki in relieving chronic pain, as an adjunct therapy which, in addition to preventing and balancing the body, greatly improves the quality of life of older people. Many of the older individuals reported using pain medications routinely, and during the five days they attended to the Reiki sessions there were reports that it had not been necessary to make use of these medications:

[...] I felt much better, I was always taking medicine, these analgesics, no, it's antibiotics [...]. I take them at night and the next day the pain has already started. Once you start doing this [Reiki], I did not take them any more and I felt my nerves being loosened (OM).

Thus, based on reports, there was an improvement in the quality of life of the older individuals subjected to this care practice, since Reiki was found to be curative and harmonizing, acting on the cause of the problem, easing the pain and making the subject feel more peaceful, balancing the body, mind and spirit, and also decreasing the intake of allopathic medicines.

The origin of a chronic problem is formed at the level of the mind and spirit over time, before revealing itself as a physical problem. When a person begins to have rheumatism at fifty, mental and spiritual causes of this imbalance have already been forming for a long time, through emotional attitudes and reactions. The symptoms of the disease are a sign of how the mind and the spirit warn us about problems at a higher level. ${ }^{19}$

It was possible to observe the expressions of pain from subjects when lying on the stretcher and in the first positions of the head until the second 
day of being submitted to care. However, after the third or fourth position of the head and the end of the sessions, it was noted that there were difficulties in moving and getting off of the stretcher, and showing a good overall appearance.

A previous study with twenty subjects had the aim to evaluate the effects of Reiki in the treatment of older patients with complaints of pain, depression and/or anxiety. Significant differences were observed between experimental and treatment groups in terms of the measurement of pain, depression and anxiety, with no changes being observed in heart rate and blood pressure. The subjects referred to relaxation, improved physical symptoms, mood and well-being; curiosity and the desire to learn were also observed, as well as increased self-care and sensory and cognitive responses to Reiki. ${ }^{20}$

It is suggested that the use of alternative therapies be built by professionals from the healthcare team, including nurses, which should contribute to the proper use of treatment resources, providing care capable of addressing other aspects beyond the biological. Results beyond the positivist paradigms can also be sought, encouraging patient autonomy in preserving their health and aiding in coping with the healing or maintaining the health of individuals under their care. ${ }^{21}$

\section{The practice of Reiki as a care tool: providing physical and psychological well-being}

Most respondents who reported feeling anxiety, nervousness and stress before the Reiki sessions indicated that, after the sessions, there was a significant improvement in symptoms, as the following statement shows:

[...] I felt more like this, it seems that my nerves were better, because at home before doing this [Reiki], I was very nervous, I felt like going out, and through the day I stayed home alone, bah! It just made me feel like eating, made me want to attack the fridge and eat everything inside [laughs]. Sometimes I would start crying, alone and nervous, you know, with pain. Not now, after these days, this week it didn't happen, this week nothing like that happened, I felt good (AUM).

Reiki is an unlimited energy of light, healing naturally through human touch, restoring balance to the body, mind and emotions. It is a comprehensive method of energy healing that gives great meaning to life, because the disease and the negative emotions unite, and healing the disease also means healing the emotions that accompany it. The Reiki energy goes right where the healing is needed, providing care in a comprehensive way. ${ }^{22}$

The method transfers energy from the donor (the Reiki channel) to the recipient, working at different levels. It harmoniously balances all aspects of the recipient's being, according to their personal needs and desires. It balances the organs and glands, and their bodily functions, it releases blockages and suppressed emotions, it promotes natural healing of beings, it adapts to the natural needs of the recipient, expanding personal awareness and helping meditative states, it relaxes and reduces stress, stimulates creativity, enhances vital energy, sharpens intuition, it treats the symptoms and causes of illness, healing holistically, strengthening the immune system, it relieves pain, and releases toxins. ${ }^{2}$

Complaints of nervousness, stress and anxiety are common among older adults, especially when they feel continuous pain. In this context, one should be attentive to the introduction of complementary practices, in order to improve the quality of life of this part of the population, since they have obtained a significant improvement in pain and, consequently, reported reduced anxiety, nervousness and stress.

Thus, it is noticed that after applying complementary therapy through Reiki, the subjects show significant improvement, especially in aspects related to chronic pain and mental health. All the respondents said that they would recommend this therapy to other subjects, due to the well-being they felt, and would do it again if they had the opportunity, as evidenced in the following quote:

[...] it gave some relief, so it appears in people who do not have that, like depression, but it is not, it's anxiety, then it is gone, it improved one hundred percent. I think we realize we need it and it makes us do it again. If I have another opportunity, if you can refer us, I want to do it again, later (GAM).

In an observatory character, most of the older individuals reached a certain degree of body relaxation after the $4^{\text {th }}$ position of the head, because for Reikians, the positions are 14 in number, four positions on the head, four positions on the front, four on the back and two on the feet. It always starts in the head, where the hands are placed at strategic points related to the chakras. It can be observed by the movement and breathing; some wanted to expose feelings experienced on a daily basis during the application. They reported feeling vibrations in the body, in the regions where 
they felt more pain. They said that the hands of the Reikian vibrated. After the $2^{\text {nd }}$ Reiki session, the subjects were more comfortable and one could observe an improvement due to a more serene and calm appearance.

Changes between the $4^{\text {th }}$ and the $5^{\text {th }}$ Reiki sessions were not observed nor reported and, therefore, it was stated that four sessions of therapy were sufficient for relief and/or improvement in complaints of chronic pain. Eight of the ten subjects slept for some time during the sessions and all of them reported drowsiness. At the end of each session, the subjects' appearance was that of serenity, observed by the calm and tranquility they showed.

A previous study ${ }^{17}$ evaluated that the Reiki therapy could produce psycho-physiological changes in older patients with symptoms of stress. It was measured in a group of volunteers who received Reiki and a group that received a placebo treatment, psychological responses such as stress levels, anxiety, depression, perceptions of tension, well-being and quality of life, as well as physiological responses to peripheral temperature, muscle tension and electrical skin conductance. The set of results obtained suggested that Reiki therapy produced psycho-physiological changes in the older adults, consistent with a significant reduction of stress.

The energy called Reiki is a method that adapts to the new paradigms of health that emerge in health care and includes awareness, body, mind, and especially prevention. In a previous study, with the aim to identify the feelings experienced by nursing professionals who worked in an ICU after the application of Reiki, the results were satisfactory, demonstrating that the professionals who undergone this therapeutic practice reported that Reiki helped to balance their physical, mental, emotional and spiritual needs, leading to a harmonious relationship between man and his environment, as well as self awareness. ${ }^{23}$

Based on this perception, it is understood that a change in this reality depends on academic training, or the professional seeking new forms of treatment in a natural way, in order to contribute to improving the health of the individual.

It becomes essential for the nurse, as a member of the healthcare team, to work from the perspective of comprehensiveness, respecting differences and the social context of each individual. ${ }^{21}$ Therefore, it is necessary that the training of nurses includes knowledge about complementary health practices, since this professional has support and legal protection for the development of Complementary and Alternative Therapies (CATs), guaranteed by Resolution 197 of March 19, 1997, of COFEN (Brazilian Federal Nursing Council). ${ }^{24}$ The same advice defines CATs as "practices mostly derived from Eastern cultures, where they are exercised or performed by systematically trained practitioners and passed on from generation to generation, not bound to any professional category". ${ }^{24}$

The search for increasingly skilled workers leads to greater investment in the training of health workers and defines the importance of a model for training/qualification policy and health education for human resources. ${ }^{25}$ Training in the health area should be considered strategic and can be constituted in a particular area for constructing expertise, policy and ethics for strengthening human resources. In this context, it becomes essential to quote the National Policy for Continuing Education in Health (EPS), created by the Ministry of Health in 2004. The EPS proposes that the transformation of professional practices must be based on critical reflection in collective spaces, in discussion groups, based on questioning the reality of work and identifying training needs. ${ }^{26}$ It is essential to establish educational proposals for maintaining a system, because there is a possibility to transcend to different ways of knowing and doing, in accordance with the social, historical, economic and political moment for promotion of the subjects and citizens aware of their professional, personal and social commitments and so they can be made effective in an integrative manner. ${ }^{27}$ Thus, one should be attentive to the need to seek strategies to empower nurses, so that these practices become routine for those working with human beings at various stages of their development.

\section{CONCLUSION}

In general, after receiving Reiki, the study participants reported activation of their energy, referring it caused the relief of their pain, while promoting body relaxation and decreasing anxiety. In conclusion, after five sessions of Reiki, a significant improvement in complaints of chronic pain was perceived through the reports of the subjects, in addition to the contribution to a balance in the mental, emotional, spiritual and physical needs of the individuals.

As they interact with the population and with patients, the nurse's role is to offer alternatives to complement the treatment, which is within reach 
of the target audience, promoting disease prevention and health promotion, aimed at providing a holistic care in a natural way, and respecting beliefs, values, the local reality of the population and the individuality of each human being.

The use of complementary health practices is a means to demonstrate professional autonomy in all forms of performance, allowing the aggregation of knowledge about cultural, economic and biopsychosocial situations, where care for the subject is found. When dealing with treating older people, complementary practices can ensure greater social interaction and an improvement in self-esteem, encouragement in performing daily activities, aspects, which in the context of the lives of these subjects, become forgotten most of the time.

\section{REFERENCES}

1. Sader M. O poder do Reiki. $1^{\text {a }}$ ed. São Paulo (SP): Pensamento; 2012.

2. Honervogt T. Reiki: cura e harmonia através das mãos. 4a ed. São Paulo (SP): Pensamento; 2005.

3. Klatt O, Lindner N. O Reiki e a medicina tradicional. $1^{a}$ ed. São Paulo (SP): Pensamento; 2009.

4. Petter FA. Manual de Reiki, do Dr. Mikao Usui. $3^{a}$ ed. São Paulo (SP): Pensamento; 2003.

5. Carvalho MMMJ. Dor, um estudo multidisciplinar. $2^{\text {a }}$ ed. São Paulo (SP): Summus; 1999.

6. Almeida ICGB, Sá KN, Silva M, Baptista A, Matos MA, Lessa I. Prevalência de dor lombar crônica na população da cidade de Salvador. Rev Bras Ortop. 2008; 43(3):96-102.

7. Delarroza MS, Furuya RK, Cabrera MAS, Matsuo T, Trelha C, Yamada KN, et al. Caracterização da dor crônica e métodos analgésicos utilizados por idosos da comunidade. Rev Assoc Med Bras. 2008; 54(1):36-4.

8. Ministério da Saúde (BR). Política Nacional de Práticas Integrativas e Complementares no SUS. Brasília (DF): MS; 2006.

9. Rodrigues DMO, Hellmann F, Sanches MP. A naturologia e a interface com as racionalidades médicas. Cad Acad Tubarão. 2011; 3(1):24-36.

10. Mackay N, Hansen S, Mcfarlane O. Autonomic nervous system changes during Reiki treatment: a preliminary study. J Altern Complement Med. 2004 Dec;10(6):1077-81.

11. Fleisher KA, Mackenzie ER, Frankel ES, Seluzicki C, Casarett D, Mao JJ. Integrative Reiki for cancer patients: a program evaluation. Integr Cancer Ther. 2014; 13(1):62-7.

12. Minayo MCS. O desafio do conhecimento: pesquisa qualitativa em saúde. $8^{\mathrm{a}}$ ed. São Paulo (SP): Hucitec; 2007.
13. Ferrell BA. Pain management. Clin Geriatr Med. 2000 Nov; 16(4):853-74.

14. Bardin L. Análise de conteúdo. $7^{\mathrm{a}}$ ed. Lisboa (PT): Edições 70; 2009.

15. Ministério da Saúde (BR). Conselho Nacional de Saúde, Comissão Nacional de Ética em pesquisa. Resolução n. 196 de 10 de outubro de 1996: diretrizes e normas regulamentares de pesquisa envolvendo seres humanos. Brasília (DF): MS; 1996.

16. Cunha LL, Mayrink WC. Influência da dor crônica na qualidade de vida em idosos. Rev Dor. 2011 AbrJun; 12(2):120-4.

17. Oliveira RMJ. Avaliação de efeitos da prática de impostação de mãos sobre os sistemas hematológico e imunológico de camundongos machos [dissertação na internet]. São Paulo (SP): Universidade de São Paulo. Faculdade de Medicina da Universidade de São Paulo; 2003 [acesso 2012 Jan 10]. Disponível em: http://www.amebrasil.org.br/html/Disserta_o_ de_Mestrado__Oliveira_RMJ.pdf

18. Rodriguez LD, Morales MA, Vilanueva IC, Lao CF, Polley M, Peñas CF. Uma sessão de Reiki em enfermeiras diagnosticadas com síndrome de Burnout tem efeitos benéficos sobre a concentração de IgA salivar e a pressão arterial. Rev Latino-Am Enferm [online]. 2011 [acesso 2012 Jan 15]; 19(5). Disponível em: www.scielo.br/pdf/rlae/v19n5/ pt_10.pdf

19. Mckenzie E. A cura pelo Reiki. 1ª ed. São Paulo (SP): Manole; 2006.

20. Richeson NE, Spross JA, Lutz K, Penq C. Effects of Reiki on anxiety, depression, pain, and physiological factors in community-dwelling older adults. Res Gerontol Enferm. 2010 Jul; 3(3):187-99.

21. Saraiva KVO, Costa LB, Ximenes LB. Prática de enfermagem com terapias alternativas em adolescentes grávidas. Texto Contexto Enferm. 2003 Abr-Jun; 12(2):151-7.

22. Stein D. Reiki essencial. $11^{\text {a }}$ ed. São Paulo (SP): Pensamento; 2011.

23. Salomé de GM. Sentimentos vivenciados pelos profissionais de enfermagem que atuam em Unidade Terapia Intensiva, após aplicação do Reiki. Rev Bras Enferm. 2009 Mar; 62(6):54-8.

24. Resolução COFEN 197/1997. Portal da Enfermagem [Internet]. [acesso 2012 Jan 09]. Disponível em: http:// portaldaenfermagem.com.br/legislacao_ read.asp?id $=292$

25. Melo MLC, Nascimento MAA. Treinamento introdutório para enfermeiras dirigentes: possibilidades para a gestão do SUS. Rev Bras Enferm [online]. 2003 [acesso 2012 Jan 15]; 56(6):67477. Disponível em: http://www.scielo.br/pdf/ reben/v56n6/a17v56n6.pdf

26. Ministério da Saúde (BR). Secretaria de Gestão do Trabalho e da Educação na Saúde, Departamento 
de Gestão da Educação na Saúde. Política de educação e desenvolvimento para o SUS: caminhos para a educação permanente em saúde. Brasília (DF): MS; 2004.
27. Silva LAA, Franco GP, Leite MT, Pinno C, Lima VML, Saraiva N. Concepções educativas que permeiam os planos regionais de educação permanente em saúde. Texto Contexto Enfem. 2011 Abr-Jun; 20(2):340-8. 